Digital Press Social Sciences and Humanities

The Role of Social Media for Tourist Visit Decision on Kakilangit Market Bantul, Yogyakarta

Singgih Tri Wibowo, Althariq Meijreno Putra, Bella Ayu Yustin, Larasati Puspita Dewi and Muhammad Aditya A. Pratama

Proceeding of Indonesia Heritage Tourism Forum 2019 (IHTF 2019)

Dewi Pratika Ayu Dhira Pradati (eds) 


\title{
The Role of Social Media for Tourist Visit Decision on Kakilangit Market Bantul, Yogyakarta
}

\author{
Singgih Tri Wibowo*, Althariq Meijreno Putra, Bella Ayu Yustin, Larasati Puspita Dewi, \\ Muhammad Aditya A. Pratama \\ Travel Industry Study, STP NHI Bandung, Bandung, Indonesia \\ *e-mail: sih@stp-bandung.ac.id
}

\begin{abstract}
The emergence of social media as one of the new media has brought important changes to the world of tourism. Social media has given space to interact with each other. Various types of social media are very popular for young people, including Facebook, Path, Twitter, and Instagram, and others. Social media offers a different experience for tourists in getting information about products and services in tourism. This study aims to examine the impact of social media on tourist behavior. The respondents of this study were tourists who visited the Kakilangit Market, Bantul, Yogyakarta. This study uses quantitative analysis techniques. The results of this study found that social media influences the behavior of tourists in choosing and deciding about the attractions they will visit. The study also found that tourists use social media to communicate, looking for tourist references, as long as they travel. Furthermore, tourists will also share their experiences while traveling on social media. Social media raises the trend of new tourist objects popularized by posting photos and videos by social media users. Photos and videos uploaded on Instagram for example, represent what is owned by a tourist object or even show facts about the condition of a tourist attraction. This certainly will affect the behavior of consumers as tourists so that Instagram provides the possibility of new opportunities and challenges for tourism actors. Tourism actors are required to understand consumer behavior, especially young people as users of social media in order to design the right marketing strategy for their products.
\end{abstract}

\section{Keywords}

behavior, social media, visiting decisions

\section{Introduction}

Tourism is a series of activities and the provision of services both for tourist attraction needs, transportation, accommodation, and other services intended to meet the needs of a person or group. The trip he did only temporarily left his place of residence with the intention of resting, doing business, or other purposes (Sugiama, 2011). The rapid development of technology in the present day has a number of concepts related to digitization in various aspects and sectors one of which is the tourism sector.

"However, what is new is the concept of digitally enhanced tourism. Through the use of technology, the aim is to further improve the quality or extent of a tourist experience" (Uriely, 2005).

Digital Tourism is a digitally enhanced tourism concept. With the use of technology, the aim is to further improve the quality or increase the level of the tourist experience, meaning digital tourism is a concept based on digital using technology that aims to provide experience to travelers in the activity. One of the digital support during tour activities is social media (Benyon, Quigley, O'Kefee, \& Riva, 2014). Social media in the world of tourism is a new thing because the emergence of social media itself is still relatively new. Social Media as a part of the digital technology revolution is connecting travelers with opinions and recommendations of millions of people, including friends on their social networks and similar travelers they have never met (Mukherjee \& Nagabhushanam, 2013).

The role of social media in the tourism aspect is important especially in the search for information and making a decision behavior, but also for promotion which focused on the interaction with consumers through social media. One of the attractions or destinations that have been utilizing social media as a promotional strategy is The Kakilangit market which is located in the tourist village of the skyline of Bantul Regency, D.I. Yogyakarta. Tourist Attractions of Kakilangit Market has been in place since 2016, 
but the Ministry of Tourism in cooperation with the Indonesian Enchantment Generation or the new GENPI implemented a promotional strategy through social media since 6 months ago, therefore The Kakilangit Market is officially designated as a digital destination. This model of promotional strategy through social media is expected to attract more tourists to The Kakilangit market.

Digital Tourism can be defined as a digitally enhanced tourism concept. With the use of technology, the goal is to further improve quality or increase the level of traveler experience (Uriely, 2005). Digital tourism can be defined in two ways: traveling from here to there without "leaving your chair" and the way "critical digital tourism studies define a new cross-disciplinary field where the sociality of virtual tourism interactions is examined (entailing the Study of structures, social rules, ideologies, power relations, sustainability dimensions, ethics, and cultural values shaping digital tourism)" (Caraivan, 2017).

\section{Methods}

In conducting our research, we used the method of quantitative descriptive. The research method can be interpreted as a scientific way to obtain data which is valid with the aim of being found, developed, and substantiated, a certain knowledge so that in turn can be used to understand, solve and anticipated problems (Sugiyono, 2012).

With this method, the author intends to collect historical data and observe carefully about certain aspects related to the problem that is being researched by the author so that it will obtain data that can support the preparation of Research reports. The data obtained was then processed and further analyzed based on the theory that has been studied, thus obtaining an overview of the object and can be inferred on the issue studied. The population used in this study was tourists visiting The Kakilangit market. The population in this study is unknown in number. According to (Riduwan \& Akdon, 2013), the formula in calculating the samples in the unknown population are as follows:

$$
\mathrm{N}=\left(\frac{Z_{a / 2^{\sigma}}}{e}\right)^{2}=\left(\frac{(1,96) \cdot(0,25)}{0,05}\right)^{2}=96,04
$$

The sampling technique we use is Accidental Sampling. The data collection methods we use include:

A. The questionnaire method is a data collection technique done by giving a set of questions or written statements to the respondent to be answered by the respondent (Sugiyono, 2004).

B. The interview method is the data collection method by doing a question and answer directly to the manager of The Kakilangit market.

\section{Findings and Discussion}

The dissemination of the questionnaires was physically done in the area of the semi-Kakilangit market. The survey was carried out every weekend, namely Saturday and Sunday according to the schedule of operations semi-Kakilangit. The research team also conducts a spread of questionnaires online to capture the respondents who have visited The Kakilangit market, the way of the distribution is to ask the research relatives who reside in Yogyakarta and surrounding whether they Have a colleague or relative who has visited the previous Kakilangit market. A total of 50 physical questionnaires and 60 online questionnaires were gathered by the research team, but as many as 5 online questionnaires were considered not valid and unable to be analytic. Five online questionnaires could not be processed due to less complete and inconsistent content. Therefore, the total data of respondents managed to obtain 105 respondents. The research team uses a quantitive analysis with a frequency distribution technique. Data processing is done with Microsoft Excel software for Windows-based devices. 


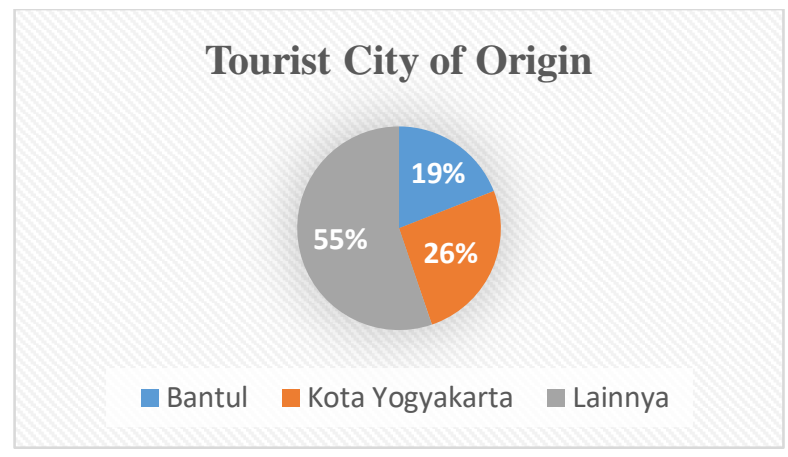

Fig. 1 Tourist City of Origin

According to data the research team is by many tourists who come from Yogyakarta City is a lot of students who visit The Kakilangit market, among students are from outside the city that is studying in Yogyakarta, but According to data from our questionnaire among the students wrote their home area even though they are actually domiciled in Yogyakarta.

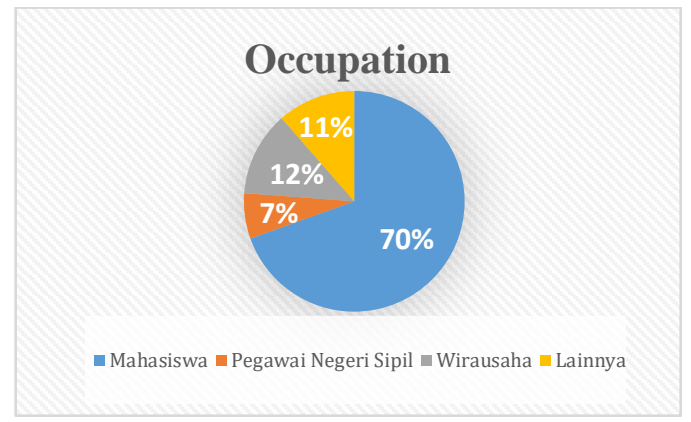

Fig. 2 Tourist Occupation

The students become the dominant occupation group who visit The Kakilangit market because students can reach information about the Semi-Kakilangit market easier due to its marketing that uses only social media platforms. They show authentic Javanese culture and especially the culinary on their official social media.

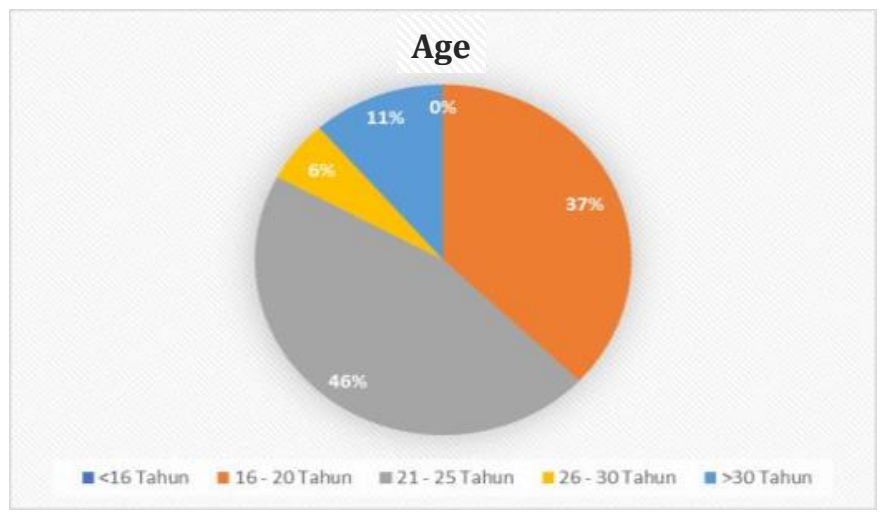

Fig. 3 Tourist Range of Age

Fig. 3 is a diagram that classifies respondents by age. The age range of 21-25 years is the most common respondent who has visited the Kakilangit market, with a number $46 \%$ or as many as 48 respondents. The age range 21-25 is an age group that often uses social media, especially to find a reference, and therefore this age range group is very easy to find information about the semi-Kakilangit market because the marketing target is social media users. 


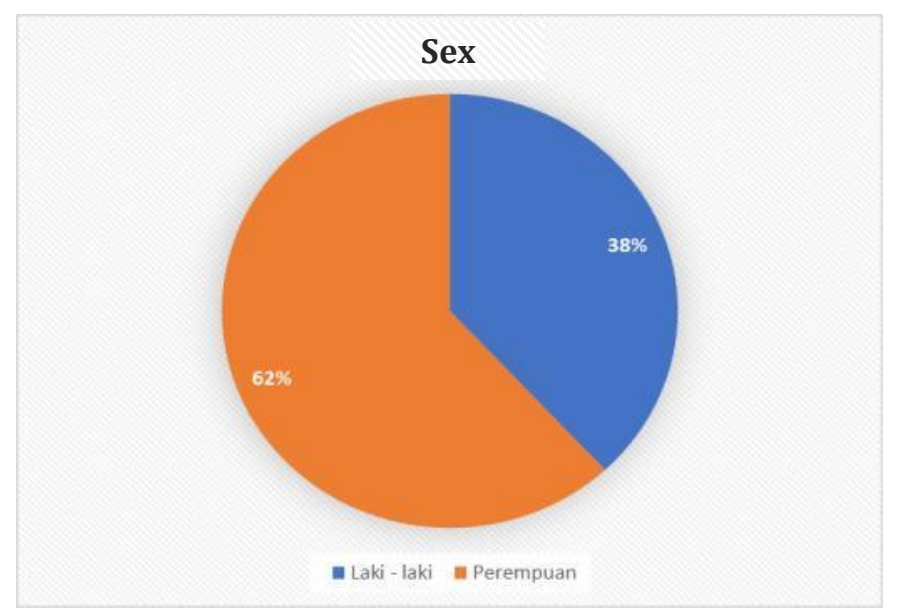

Fig. 4 Sex

The number of female tourists is much more than male travelers.

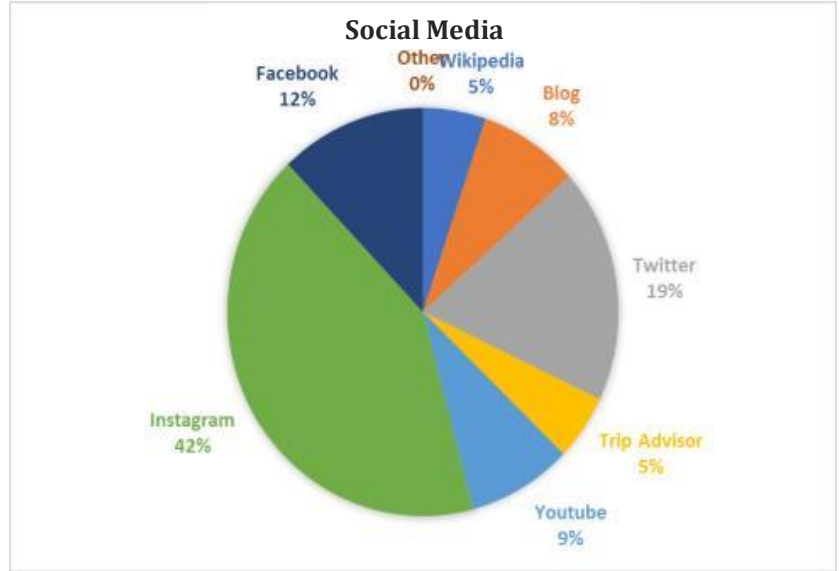

Fig. 5 Social Media

According to the data, we can know that the most used social media by our respondents is Instagram with a percentage of $42 \%$. From this data, it can be seen that the marketing strategy of the semi-Kakilangit market is appropriate because it uses an Instagram platform and content that shows authentic culinary products in Yogyakarta.

Table 1 Pre-Consumption Data Findings ( $n=105)$

\begin{tabular}{|c|c|c|c|c|c|c|c|c|}
\hline Questions & SA & A & $\mathrm{N}$ & $\mathrm{D}$ & SD & $\begin{array}{l}\text { Sub } \\
\text { Total }\end{array}$ & Total & Max \\
\hline $\begin{array}{l}\text { Social media give me information about Pasar } \\
\text { Kakilangit }\end{array}$ & 32 & 53 & 14 & 6 & 0 & 105 & 426 & 550 \\
\hline I knew Pasar Kakilangit from social media & 34 & 46 & 13 & 10 & 2 & 105 & 415 & 550 \\
\hline $\begin{array}{l}\text { After got information from social media, I } \\
\text { decided to go to Pasar Kakilangit }\end{array}$ & 39 & 41 & 18 & 4 & 3 & 105 & 424 & 550 \\
\hline $\begin{array}{l}\text { I always use social media to get the information } \\
\text { for my trip }\end{array}$ & 49 & 34 & 11 & 10 & 1 & 110 & 435 & 550 \\
\hline TOTAL & & & & & & & 1700 & 2200 \\
\hline Percentage & & & & & & & 80 & 100 \\
\hline
\end{tabular}


Table 2 Consumption Data Findings ( $n=105)$

\begin{tabular}{|c|c|c|c|c|c|c|c|c|}
\hline Questions & SA & A & $\mathrm{N}$ & $\mathrm{D}$ & SD & $\begin{array}{l}\text { Sub } \\
\text { Total }\end{array}$ & Total & Max \\
\hline $\begin{array}{l}\text { The Social Media has a contribute and reliable to } \\
\text { know Pasar Kakilangit }\end{array}$ & 26 & 53 & 21 & 5 & 0 & 105 & 415 & 550 \\
\hline $\begin{array}{l}\text { The information from social media about Pasar } \\
\text { Kakilangit are accurate and comprehensive }\end{array}$ & 14 & 59 & 29 & 3 & 0 & 105 & 399 & 550 \\
\hline $\begin{array}{l}\text { The Social media give a reliable information and } \\
\text { accurate with my experience in Pasar Kakilangit }\end{array}$ & 16 & 64 & 19 & 6 & 0 & 105 & 405 & 550 \\
\hline TOTAL & & & & & & & 1219 & 1650 \\
\hline Percentage & & & & & & & 82,5 & 100 \\
\hline
\end{tabular}

Table 3 Post-Consumption Data Findings $(n=105)$

\begin{tabular}{|c|c|c|c|c|c|c|c|c|}
\hline Questions & SA & A & $\mathrm{N}$ & $\mathrm{D}$ & SD & $\begin{array}{l}\text { Sub } \\
\text { Total }\end{array}$ & Total & Max \\
\hline $\begin{array}{l}\text { I shared my experience in Pasar Kakilangit } \\
\text { through Social Media }\end{array}$ & 37 & 41 & 19 & 4 & 4 & 105 & 418 & 550 \\
\hline $\begin{array}{l}\text { The Social Media are reliable tools for } \\
\text { promotion and I always use it }\end{array}$ & 58 & 33 & 10 & 3 & 1 & 105 & 459 & 550 \\
\hline TOTAL & & & & & & & 877 & 1100 \\
\hline Percentage & & & & & & & 83 & 100 \\
\hline
\end{tabular}

\section{Conclusion}

The Kakilangit Market offers a variety of traditional culinary, especially Yogyakarta, where we can find various types of traditional food at very affordable prices. For the payment system itself, it is very unique that visitors are required to exchange whatever amount of money with wooden coins which will later be used to buy foods or crafts at The Kakilangit Market, besides having traditional food. The Kalilangit market also provides several handicrafts as souvenirs. Not only serving food and handicrafts, this market also often displays a variety of arts such as Gojeg Lesung, Keroncongan, and Sendratari. This market is managed directly by the surrounding community but with the help and support of the ministry of tourism, and they also have their own promotion team called "GENPI" or Generasi Pesona Indonesia. Because this market is one of the digital tourism in Indonesia, the main promotion carried out to promote this market is to use Instagram social media, which greatly expects the strength of social media and millennial generation so that this market can be better known and brought more many visitors so that they can preserve special food and prosper the lives of the surrounding community.

Based on the results of the data analysis and the discussion that has been outlined in the previous chapter, it can be concluded that tourists visiting The Kakilangit market are mostly 16-20 years old, which mostly hope to have a positive experience after their visit to The Kakilangit market. It can be concluded that most visitors of The Kakilangit market agree that social media is very influential in the decision of tourists visiting the market, and almost all visitors who come to the Kakilangit market know The Kakilangit market through social media.

Visitors of The Kakilangit market are also accustomed to share their experiences through social media. Social media often used by the visitors of The Kakilangit market from pre-consumption, consumption to post-consumption during their visit to the Kakilangit market is Instagram. It can be concluded that from various social media, Instagram is selected to be the reference to share their experiences during the attractions. It is simply because Instagram as social media is rated by the visitors as the most interesting social media to use.

\section{References}

Benyon, D., Quigley, A., O’Kefee, B., \& Riva, G. (2014). Presence and digital tourism. Al \& Society, 29(4), 
$521-529$.

Caraivan, L. (2017). Digital Tourism: A review of trends in promoting tourims activities. Quaestus, 11, 159.

Mukherjee, A., \& Nagabhushanam, M. (2013). Role of Social Media in Tourism Marketing. International Journal of Sciene Research, 5(6), 2026-2033.

Riduwan, \& Akdon. (2013). Rumus dan Data dalam Aplikasi Statistika. Jakarta: Alfabeta.

Sugiama, A. G. (2011). Ecotourism: Pengembangan Pariwisata berbasis konservasi alam. Bandung: Guardaya Intimarta.

Sugiyono. (2004). Metode Penelitian. Bandung: Alfabeta.

Sugiyono. (2012). Metode Penelitian Kuantitatif, Kualitatif dan $R \& D$. Bandung: Alfabeta.

Uriely, N. (2005). The tourist experience: conceptual developments. Annals of Tourism Research, 32(1), 199216. 